\title{
Growth of three subtropical mangrove species in response to varying hydroperiod in an experimental tank
}

\section{Crecimiento de tres especies de mangle subtropical en respuesta a la variabilidad en el hidroperiodo en un tanque experimental}

\author{
Mariana Monroy-Torres ${ }^{1}$, Francisco Flores-Verdugo ${ }^{1}$, Francisco Flores-de-Santiago ${ }^{2 *}$ \\ ${ }^{1}$ Instituto de Ciencias del Mar y Limnología, Universidad Nacional Autónoma de México, \\ Unidad Académica Mazatlán, Av. Joel Montes Camarena s/n, 82040 Mazatlán, Sinaloa, México. \\ ${ }^{2}$ Instituto de Ciencias del Mar y Limnología, Universidad Nacional Autónoma de México, \\ Apartado postal 70-305, Av. Universidad 3000, Ciudad Universitaria, México DF 04510, México. \\ *Corresponding author. E-mail: floresdesantiago@gmail.com; ffloresd@cmarl.unam.mx
}

\begin{abstract}
The effect of hydroperiod on the survival and growth of Avicennia germinans, Laguncularia racemosa, and Rhizophora mangle seedlings under experimental conditions was investigated using a simulated tidal system. Seedlings of the three mangrove species were grown at four inundation levels. All levels were flooded every $12 \mathrm{~h}$ in order to create a simulated semi-diurnal tide cycle (i.e., two high tides and two low tides per day). Based on the hydroperiod for the study area, level 1 was flooded for $10 \mathrm{~h}$, level 2 for $6 \mathrm{~h}$, level 3 for $2 \mathrm{~h}$, and level 4 for 6 min. After 570 days, the results showed that $R$. mangle presented the highest growth at level 1 and the lowest growth at level 4 . The optimal growth of $L$. racemosa occurred at levels 2 and 3, but all the seedlings died at level 1, indicating that this species is highly sensitive to tidal regimes. Compared to L. racemosa and R. mangle, A. germinans had a moderate growth rate at all four levels. Mangrove growth differentiations were more prominent at levels 1 and 3, where the three species showed very different growth patterns. Studies of optimal growth using hydroperiod experiments are important in order to understand the physiological responses of mangrove forests to a possible sea level rise in the next decades, especially in subtropical environments where they are constantly exposed to stress.
\end{abstract}

Key words: hydroperiod, Avicennia germinans, Laguncularia racemosa, Rhizophora mangle.

RESUMEN. Se investigó el efecto del hidroperiodo en el crecimiento y supervivencia de plántulas de Avicennia germinans, Laguncularia racemosa y Rhizophora mangle bajo condiciones experimentales por medio de un simulador de mareas. Se colocaron plántulas de las tres especies a cuatro diferentes niveles de inundación durante $12 \mathrm{~h}$ para simular un ciclo de marea semidiurna (i.e., dos mareas altas y dos mareas bajas por día). Con base en el hidroperiodo de la zona de estudio, el nivel 1 estuvo inundado por $10 \mathrm{~h}$, el nivel 2 por $6 \mathrm{~h}$, el nivel 3 por $2 \mathrm{~h}$ y el nivel 4 por 6 min. Después de 570 días, los resultados mostraron que $R$. mangle presentó el mayor crecimiento en el nivel 1 y el menor crecimiento en el nivel 4 . El crecimiento óptimo de L. racemosa fue en los niveles intermedios 2 y 3 , pero todas las plántulas murieron en el nivel 1, lo cual nos indica que esta especie es altamente sensible a periodos prolongados de inundación. Comparado con L. racemosa y R. mangle, A. germinans presentó un crecimiento moderado en los cuatro niveles. La diferencia en el crecimiento de los manglares fue más prominente en los niveles 1 y 3 , donde las tres especies mostraron patrones muy diferentes. Los estudios sobre el crecimiento óptimo mediante simuladores de marea son importantes para entender la respuesta fisiológica de los bosques de mangle a un posible incremento en el nivel del mar en las próximas décadas, especialmente en ambientes subtropicales donde el nivel de estrés es alto.

Palabras clave: hidroperiodo, Avicennia germinans, Laguncularia racemosa, Rhizophora mangle.

\section{INTRODUCTION}

Changes in the frequency of coastal flooding resulting from sea level rise will have severe consequences worldwide (Ye et al. 2004, Gilman et al. 2008). Over the past 100 years, sea level has risen 10-20 cm (Field 1995) and caused geomorphological changes along the coastline. Mangrove forests, located at the land-ocean interface, will be one of the most affected ecosystems as a result of tide-induced changes in the hydrology of the coastal zone, especially the hydroperiod. Variability during flood periods is known to cause changes in the physiology, growth, and reproduction of several mangrove species (Ellison and Farnsworth 1997).

\section{INTRODUCCIÓN}

Los cambios en la frecuencia de inundación costera como resultado de una elevación en el nivel del mar van a tener consecuencias severas a nivel mundial (Ye et al. 2004, Gilman et al. 2008). En los últimos 100 años, el nivel del mar se ha elevado de 10 a $20 \mathrm{~cm}$ (Field 1995), y esto ha ocasionado cambios geomorfológicos en la línea de costa. Debido a su ubicación en la interface tierra-océano, los bosques de mangle van a ser uno de los ecosistemas más afectados ante un cambio en la hidrología de la zona costera, en particular el hidroperiodo controlado por mareas. Se ha estimado que la variabilidad en el periodo de inundación ocasiona cambios en 
Therefore, studies on mangrove growth and survival under different inundation conditions are necessary to be able to predict the long-term physiological responses.

Mangroves are the trees most capable of tolerating saline conditions in tropical and subtropical intertidal areas (McKee 1995, Blasco et al. 1996, Saenger 2002, Spalding et al. 2010). Mangrove forests are important because they have the ability to improve ecological aspects such as organic carbon dynamics (Flores-Verdugo et al. 1987, Bashan and Holguin 2002, Kristensen et al. 2008) and primary productivity (Holguin et al. 2001, Dittmar et al. 2006), and they provide protection against hurricanes and tropical storms (Raven et al. 1992, Gilman et al. 2008, Komiyama et al. 2008). Despite their ecological importance, mangrove forests around the world are constantly exposed to anthropogenic disturbances such as port development in the coastal zone, expansion of the agricultural frontier, and aquaculture expansion (Duke et al. 2007, Polidoro et al. 2010, Spalding et al. 2010).

More research is needed on the distribution of mangrove species in tropical and subtropical tidal areas to better understand their capacity to cope with a possible rise in sea level. Mangrove zonation patterns have been studied over the past decades (Bunt et al. 1985, Tomlinson 1986, Bunt 1996, Allen et al. 2003, He et al. 2007). The influence of sea level change on the zonation of mangrove species depends on several factors, including interspecific competition (Ye et al. 2003, Cardona-Olarte et al. 2006), environmental response (Ellison et al. 2000, Dahdouh-Guebas et al. 2004), propagule dispersal and establishment (AboEl-Nil 2001, Delgado et al. 2001), seedling predation (Ellison and Farnsworth 1993, McKee 1995), physiological adaptations to flooding (Khan and Aziz 2001, Allen et al. 2003, Krauss et al. 2006, He et al. 2007, Wang et al. 2007, Xiao et al. 2009, Xiao et al. 2010, Ye et al. 2010), and the response to hydrodynamic and geomorphologic changes (Bunt 1996, Bryce et al. 2003). Few studies, however, have examined the relative importance of these factors for mangrove species (McGuinness 1997).

The traditional zonation of tropical mangrove forests along the American continent's coastline exhibits a characteristic pattern: the black mangrove, Avicennia germinans (L) Stern, is usually found at interior sites, on higher ground where flooding is less frequent; the white mangrove, Laguncularia racemosa (L) Gaertn., occurs at sites where moderate flooding and salinity conditions prevail; and the red mangrove, Rhizophora mangle L, dominates fringe areas influenced by the tide (McKee 1995). While this is the typical zonation pattern of tropical mangrove forests, Kovacs et al. (2011, 2013a, 2013b) and Flores-de-Santiago et al. (2012, 2013a, 2013b) found that it is not so common in subtropical regions where there are two main physiographic types of mangrove forests: fringe and basin. Hence, along semi-arid, subtropical coasts, the three mangrove species are distributed parallel to tidal channels (i.e., healthy conditions) and close la fisiología, crecimiento y reproducción de varias especies de mangle (Ellison y Farnsworth 1997). Por lo tanto, se necesitan trabajos sobre el crecimiento y la supervivencia de varias especies de mangle bajo diferentes condiciones de inundación para poder predecir las respuestas fisiológicas a largo plazo.

Los mangles son los árboles más adaptados para tolerar condiciones salinas en zonas intermareales tropicales y subtropicales (McKee 1995, Blasco et al. 1996, Saenger 2002, Spalding et al. 2010). Los bosques de mangle son importantes porque tienen las facultades de mejorar aspectos ecológicos como la dinámica de carbono orgánico (FloresVerdugo et al. 1987, Bashan y Holguin 2002, Kristensen et al. 2008, ) y productividad primaria (Holguin et al. 2001, Dittmar et al. 2006), además actúan como zona de protección contra huracanes y tormentas tropicales (Raven et al. 1992, Gilman et al. 2008, Komiyama et al. 2008). A pesar de su importancia ecológica, los bosques de mangle están bajo constante degradación a nivel mundial debido a disturbios antropogénicos como el desarrollo de puertos en la zona costera, la ampliación de la frontera agropecuaria y la expansión de la acuacultura (Duke et al. 2007, Polidoro et al. 2010, Spalding et al. 2010).

Se necesitan más estudios sobre la distribución de las especies de mangle en la zona intermareal de las costas tropicales y sobtropicales para poder entender su respuesta a un posible cambio en el nivel del mar. Los patrones en la zonación de especies de mangle han sido tema de investigación en las última décadas (Bunt et al. 1985, Tomlinson 1986, Bunt 1996, Allen et al. 2003, He et al. 2007). La influencia del nivel del mar en la zonación de especies de mangle depende de varios factores, los cuales incluyen competencias interespecíficas (Ye et al. 2003, Cardona-Olarte et al. 2006), respuestas ambientales (Ellison et al. 2000, Dahdouh-Guebas et al. 2004), dispersión y establecimiento de propágulos (AboEl-Nil 2001, Delgado et al. 2001), depredación de plántulas (Ellison y Farnsworth 1993, McKee 1995), adaptaciones fisiológicas a inundaciones (Khan y Aziz 2001, Allen et al. 2003, Krauss et al. 2006, He et al. 2007, Wang et al. 2007, Xiao et al. 2009, Xiao et al 2010, Ye et al. 2010) y respuesta a cambios hidrodinámicos y geomorfológicos (Bunt 1996, Bryce et al. 2003). Sin embargo, la importancia de estos factores ha sido investigada sistemáticamente para sólo unas especies de mangle (McGuinness 1997).

En el continente americano, la zonación tradicional de los manglares en las latitudes tropicales describe un patrón muy característico: el mangle negro, Avicennia germinans (L) Stearn, se encuentra usualmente cerca de la marisma, a un nivel elevado donde la inundación es poco frecuente; el mangle blanco, Laguncularia racemosa (L) Gaertn., se localiza donde prevalecen patrones moderados de inundación y salinidad; y el mangle rojo, Rhizophora mangle L, domina las zonas de borde cerca del canal de inundación de regiones con influencia de marea (McKee 1995). A pesar de que el patrón descrito anteriormente es típico de los bosques de mangle en 
to the high marsh zone (i.e., stress conditions). In situations where the intertidal environment is considered more variable and complex, the traditional definition of zonation patterns is not feasible.

Identifying species distribution patterns and determining the physiological mechanisms continues to be one of the main objectives of ecologists (Ellison et al. 2000). Little information is available on the tolerance of subtropical mangroves to changes in soil salinity. This information is important to be able to predict physiological changes resulting from a possible rise in sea level (Gilman et al. 2008). The growth and physiological mechanisms of mangrove forests in arid regions differs amongst species because of the complexity of their internal structure and differences in flooding regimen, tidal influence, nutrients, and type of soil (Khan and Aziz 2001).

In arid regions, propagule establishment depends on the response of mangroves to physiological stress caused by intertidal environments (Bashan and Holguin 2002, CardonaOlarte et al. 2006). Under natural conditions, the establishment of mangrove species is related to their adaptability and tolerance to flooding. Despite the special adaptability exhibited by mangroves to saline conditions, their tolerance is limited to the frequency and duration of the local tides (AboEl-Nil 2001). Therefore, in subtropical environments, the hydroperiod, which includes flood duration, frequency, and area, is the main factor affecting mangrove growth (Krauss et al. 2006, Bashan et al. 2013). The objective of the present study was to study the growth, survival, and tolerance of three subtropical mangrove species from the Pacific coast of Mexico exposed to different periods of tidal inundation. Our hypothesis was that the three mangrove species would exhibit differences in behavior and survival depending on the length of the inundation period.

\section{MATERIALS AND METHODS}

\section{Study area}

The Urías lagoon system is located on the Pacific coast of Mexico, just south of the mouth of the Gulf of California $\left(23^{\circ} 09^{\prime} \mathrm{N}, 106^{\circ} 19^{\prime} \mathrm{W}\right)$. This coastal lagoon is shallow and saline, and presents constant vertical mixing. It covers an area of $18 \mathrm{~km}^{2}$ and its main channel empties into the Pacific Ocean. Mean annual temperature ranges from 24 to $26^{\circ} \mathrm{C}$. Rainfall mainly occurs in July and August, and total annual rainfall is between 800 and $1000 \mathrm{~mm}$ (INEGI 2012). This subtropical lagoon system has tidal channels, a temporary floodplain, and a considerable mangrove community (Floresde-Santiago et al. 2012, 2013a, 2013b). Three mangrove species are found in this coastal lagoon: the black mangrove, A. germinans; the white mangrove, L. racemosa; and the red mangrove, $R$. mangle. zonas tropicales, Kovacs et al. (2011, 2013 a, 2013b) y Flores-de-Santiago et al. (2012, 2013a, 2013b) encontraron que este patrón no es tan común en regiones subtropicales, donde la clasificación fisiognómica de las tres especies puede ser de tipo cuenca y borde. En otras palabras, en las costas semiáridas subtropicales, las tres especies de mangle pueden estar distribuidas paralelas al canal de inundación (i.e., condición saludable) y cerca de la zona elevada de la marisma (i.e., condición estresada). En situaciones donde el ambiente intermareal es considerado más variable y complejo, la definición tradicional de patrones de zonación no es factible.

La identificación de patrones en la distribución de mangles y la determinación de los mecanismos fisiológicos continuan siendo uno de los principales objetivos de ecologistas (Ellison et al. 2000). Existe muy poca información sobre la tolerancia de los mangles subtropicales a la salinidad del suelo asociada a cambios hidrológicos. Esta información sería de gran importancia para poder predecir los cambios fisiológicos debido a los posibles incrementos en el nivel del mar (Gilman et al. 2008). Sin embargo, el crecimiento y los mecanismos fisiológicos de los bosques de mangle en zonas áridas difieren entre especies debido a la complejidad de su estructura interna y a las diferencias en el régimen de inundación, influencia de mareas, nutrientes, y tipo de suelo (Khan y Aziz 2001).

En regiones áridas, el establecimiento de propágulos depende de la respuesta de los mangles al estrés físiológico causado por los ambientes intermareales (Bashan y Holguin 2002, Cardona-Olarte et al. 2006). Bajo situaciones naturales, el establecimiento de las especies de mangle esta relacionado a la adaptabilidad y tolerancia a las inundaciones. A pesar de que los mangles tienen una adaptabilidad especial a condiciones de agua salada, su resistencia a la salinidad esta limitada a la frecuencia y duración de las mareas locales (AboEl-Nil 2001). Por tal motivo, en ambientes subtropicales, el hidroperiodo, que incluye la duración, frecuencia y área de inundación, es el factor más importante en afectar el crecimiento del mangle (Krauss et al. 2006, Bashan et al. 2013). El objetivo del presente estudio fue investigar el crecimiento, la supervivencia y la tolerancia de tres especies de mangle subtropical de las costas mexicanas del Pacífico expuestos a diferentes periodos de inundación controlados por cambios en el nivel del mar. Nuestra hipótesis fue que las tres especies de mangle presentarían diferencias en el comportamiento y la supervivencia dependiendo del periodo de inundación.

\section{MATERIALES Y MÉTODOS}

\section{Área de estudio}

El sistema lagunar de Urías se localiza en la costa mexicana del Pacífico, al sureste del golfo de California $\left(23^{\circ}\right.$ $09^{\prime} \mathrm{N}, 106^{\circ} 19^{\prime} \mathrm{W}$. La laguna costera de Urías es un cuerpo de agua somero y salino, y presenta una mezcla vertical 


\section{Mangrove zonation}

This study was designed to determine the factors that influence the vertical distribution of mangroves in a subtropical, arid ecosystem. The three mangrove species typical of the Urías system (A germinans, L. racemosa, and $R$. mangle) are found in monospecific forests along the main tidal channel (i.e., fringe type) and close to the salt marsh (i.e., basin type), making this coastal lagoon more complex and difficult to study with traditional mangrove zonation patterns. To evaluate the topographic profile, four sites with monospecific and interspecific forests were selected based on the site descriptions given by Flores-de-Santiago et al. (2012). For all the sites, we used tidal amplitude data for the port of Mazatlán (based on the dominant semidiurnal harmonic constituent M2) made freely available by the Centro de Investigación Científica y de Educación Superior de Ensenada (http://predmar.cicese.mx/). The tidal phase lag due to the $12-\mathrm{km}$ distance between the study area and Mazatlán had to be taken into account. To be able to calibrate the tidal amplitude with the zonation transects, a tide pole was installed in the main tidal channel, and the time and height of a semidiurnal cycle were recorded. At each site, a 20-m longitudinal transect was established from the tidal channel to the salt marsh using a compass. The topographic height was measured every meter using the microtopography techniques described by García-Márquez (1985). At each topographic point, the mangrove species were classified based on physiognomy (Gilmore and Snedaker 1993).

\section{Propagule collection and experimental nursery system}

Propagules of A. germinans, L. racemosa, and R. mangle were collected during the summer from the Urías coastal lagoon. The samples were transported in plastic containers to the laboratory and placed in water having a salinity of 5 to prevent fungal propagation. Water changes were perfomed daily until the propagules were planted in the experimental tank. A mixed substrate $(2: 1: 1)$ was used consisting of a commercial substrate (Sunshine) that contained 70-80\% Canadian sphagnum peat, vermiculite, limestone (for $\mathrm{pH}$ adjustment), and agricultural gypsum (Agrimex); river soil; and sawdust (mainly pine sawdust), which was washed several times before mixing into the commercial substrate. A total of 2102 propagules were planted: 704 A. germinans propagules, $768 \mathrm{~L}$. racemosa propagules, and $630 \mathrm{R}$. mangle propagules. Four weeks after collection, irrigation was performed with saline water (5). The salinity of the irrigation water was then progressively increased to 15 , the optimum salinity for the growth of these mangrove species (FloresVerdugo et al. 1987, Khan and Aziz 2001, De-León-Herrera et al. in press). Linear equations were used to quantify seedling growth based on the change in plant height relative to the time elapsed. constante. Se extiende por $18 \mathrm{~km}^{2}$ y su canal principal desemboca en el océano Pacífico. La temperatura anual promedio oscila entre 24 y $26^{\circ} \mathrm{C}$. La precipitación ocurre principalmente entre julio y agosto, y la precipitación total anual es de 800 a 1000 mm (INEGI 2012). Esta laguna subtrópical tiene canales de marea, una llanura de inundación temporal y una comunidad considerable de mangles (Floresde-Santiago et al. 2012, 2013a, 2013b). Tres especies de mangle se encuentran en esta laguna costera: el mangle negro, A. germinans; el mangle blanco, L. racemosa; y el mangle rojo, $R$. mangle.

\section{Zonación de mangles}

Este estudio fue diseñado para determinar los factores que influyen en la distribución vertical de mangles en un ecosistema árido subtropical. Las tres especies de mangle típicas del sistema lagunar de Urías (A. germinans, L. racemosa y $R$. mangle) pueden ser encontradas en bosques monoespecíficos a lo largo del canal principal de inundación (i.e., tipo borde) y cerca de la marisma (i.e., tipo cuenca), lo cual hace que este sistema costero sea muy complejo y difícil de determinar con los patrones tradicionales de zonación de mangle. Para poder evaluar el perfil topográfico, se seleccionaron cuatro zonas con bosques monoespecíficos e interespecíficos de acuerdo con las localidades descritas por Floresde-Santiago et al. (2012). Para todas las zonas, utilizamos datos de la amplitud de marea para el puerto de Mazatlán (a partir de los armónicos dominantes semidiurnos M2) obtenidos de un programa gratuito del Centro de Investigación Científica y de Educación Superior de Ensenada (http://predmar.cicese.mx/). Fue necesario considerar el desfase de la amplitud de marea debido a una separación de aproximadamente $12 \mathrm{~km}$ entre la zona de estudio y el puerto de Mazatlán. Para poder calibrar la amplitud de marea con los transectos de zonación, se instaló un estadal en el canal principal de mareas, y se registró el tiempo y la altura de un ciclo semidiurno. En cada uno de los transectos se trazó una línea longitudinal de $20 \mathrm{~m}$ desde el canal de mareas hasta la marisma con la ayuda de una brújula. Se midió la altura topográfica cada metro mediante las técnicas de microtopografía descritas por García-Márquez (1985). Se caracterizaron las especies de mangle en cada uno de los puntos topográficos de acuerdo con su condición fisiognómica (Gilmore y Snedaker 1993).

\section{Recolecta de propágulos e instalación del vivero experimental}

Se recolectaron propágulos de A. germinans, L. racemosa y $R$. mangle en los meses de verano a lo largo de la laguna costera Urías. Todas las muestras fueron transportadas en contenedores de plástico al laboratorio y colocadas en agua con 5 de salinidad para evitar la propagación de hongos. Se realizaron cambios de agua diariamente hasta el día de la 


\section{Tide simulator}

A $11.9-\mathrm{m}^{3}$ concrete tank $(3.8 \mathrm{~m}$ in diameter and $2.2 \mathrm{~m}$ deep) was specifically built for this experiment (fig. 1). The objective was to recreate a semidiurnal tidal cycle and hydroperiod range of a typical subtropical area of the Pacific coast of Mexico at different topographical heights. Two 1.5-HP industrial pumps (calibrated using Siemens LOGO program) were used to inundate the tank. The tank was divided into four blocks, which in turn were divided into four platforms that constituted the different inundation levels at the different heights. The four blocks were interconnected by a main channel in the center of the tank to allow the water to circulate freely through them (fig. 1). The salinity of the water in the tank was maintained constant at 15 .

The inundation periods consisted of 12 -h cycles to simulate two high tides and two low tides per day. The hydroperiod conditions, however, differed for each inundation level: level 1, representing the zone that experiences prolonged inundation (i.e., sublittoral), was flooded for $10 \mathrm{~h}$; levels 2 and 3 were flooded for 6 and $2 \mathrm{~h}$, respectively; and level 4, representing the elevated supralittoral zone, was flooded for $6 \mathrm{~min}$. In view of the difficulty of maintaining the sediment on a slope, individual wooden boxes were built with 1-inch perforations to allow water flow. Levels 2, 3, and 4 were sustained by PVC pipes (4 inches in diameter). The wood was covered with epoxy paint to withstand the immersion in water, and a plastic cover was used to prevent the sediment from having direct contact with the paint. Each platform had $20 \mathrm{~cm}$ of substrate: a 2-cm-thick layer of coarse sand on the bottom, then $3 \mathrm{~cm}$ of sea sand, and finally natural substrate collected during a low tide. A total of 16 seedlings of the three mangrove species were randomly planted in each of the four compartments to be able to evaluate the interspecific responses.

\section{RESULTS}

\section{Subtropical mangrove zonation}

The tidal amplitude in this area ranges from $130 \mathrm{~cm}$ (spring tide) to $50 \mathrm{~cm}$ (neap tide). The coastal lagoon presents a variety of mangrove zonation patterns depending on the topographic profile, slope, and distance from the main tidal channel. Mangrove forests displaying a typical zonation in this lagoon system are found at sites with gentle slopes and intense tidal action. At such a site, the vegetation in the sublittoral zone is dominated by $R$. mangle, which is inundated most of the time (fig. 2a). The mid-intertidal zone is dominated by $L$. racemosa and dense A. germinans shrubs. Species composition in the supralittoral zone consists of scattered A. germinans shrubs close to the salt marsh. In an area occupied by a fringe $A$. germinans forest, there is an abrupt change in the topographic profile along the main tidal siembra en el vivero experimental. Se preparó una mezcla (2:1:1) compuesta de un sustrato comercial Sunshine que contenía $70-80 \%$ de turba canadiense esfagnácea, vermiculita, piedra caliza (para ajustar el $\mathrm{pH}$ ) y yeso agrícola (Agrimex) como ingredientes principales; tierra de río; y aserrín (principalmente madera de pino), el cual se lavó varias veces con agua corriente antes de mezclarlo con el sustrato comercial. En total, se sembraron 2102 propágulos para la germinación: 704 propágulos de A. germinans, 768 propágulos de L. racemosa y 630 propágulos de $R$. mangle. A la cuarta semana de la recolecta, el riego se realizó con agua salobre a 5 de salinidad. Luego, la salinidad del agua se fue incrementando progresivamente a 15 , la salinidad óptima para el desarrollo de estas tres especies (Flores-Verdugo et al. 1987, Khan y Aziz 2001, De-León-Herrera et al. in press). El crecimiento de las plántulas fue cuantificado mediante ecuaciones lineales como el cambio en la altura de la planta respecto al tiempo transcurrido.

\section{Simulador de mareas}

Se construyó un tanque experimetal de concreto de $11.9 \mathrm{~m}^{3}$ (3.8 $\mathrm{m}$ de diámetro por $2.2 \mathrm{~m}$ de prfundidad) (fig. 1). El objetivo fue recrear la marea semidiurna y los intervalos del hidroperiodo de una zona típica subtropical de la costa mexicana del Pacifico a diferentes alturas topográficas. Utilizamos dos bombas industriales de $1.5 \mathrm{HP}$, calibradas con el programa Logo de Siemens, para poder inundar el tanque de concreto. El tanque experimental fue dividido en cuatro bloques, y estos bloques a su vez fueron divididos en cuatro plataformas que constituían los diferentes niveles de inundación a las diferentes alturas (fig. 1). Los cuatro compartimentos estaban interconectados por un canal principal, localizado a la mitad del tanque, para permitir que el agua circulara entre ellos. La salinidad del agua en el tanque fue mantenida constante a 15 .

Los periodos de inundación fueron en ciclos de $12 \mathrm{~h}$ para simular dos mareas altas y dos mareas bajas por día. Sin embargo, cada nivel de inundación representó características de hidroperiodo propias: el nivel 1 fue inundado por $10 \mathrm{~h} \mathrm{y}$ representaba las zonas de inundación prolongada (i.e., sublitoral); los niveles 2 y 3 fueron inundados por 6 y $2 \mathrm{~h}$, respectivamente; y el nivel 4 fue inundado por 6 min y representaba la zona elevada supralitoral. Debido a la dificultad de mantener el sedimento en una pendiente, se construyeron cajones individuales de madera con perforaciones de una pulgada de diámetro para favorecer el flujo del agua. Los niveles 2, 3 y 4 estaban sostenidos por tubos de PVC de cuatro pulgadas de diámetro. La madera fue recubierta con pintura epóxica para protegerla durante el proceso de inmersión en agua, y cada cajón también tenía una cubierta de plástico para evitar el contacto directo de la pintura con el sedimento. Cada plataforma tenía $20 \mathrm{~cm}$ de sustrato: en la base había una capa de $2 \mathrm{~cm}$ de grava, luego una capa de $3 \mathrm{~cm}$ de arena de mar y el resto era sustrato natural extraído de un bajo de mareas. En 

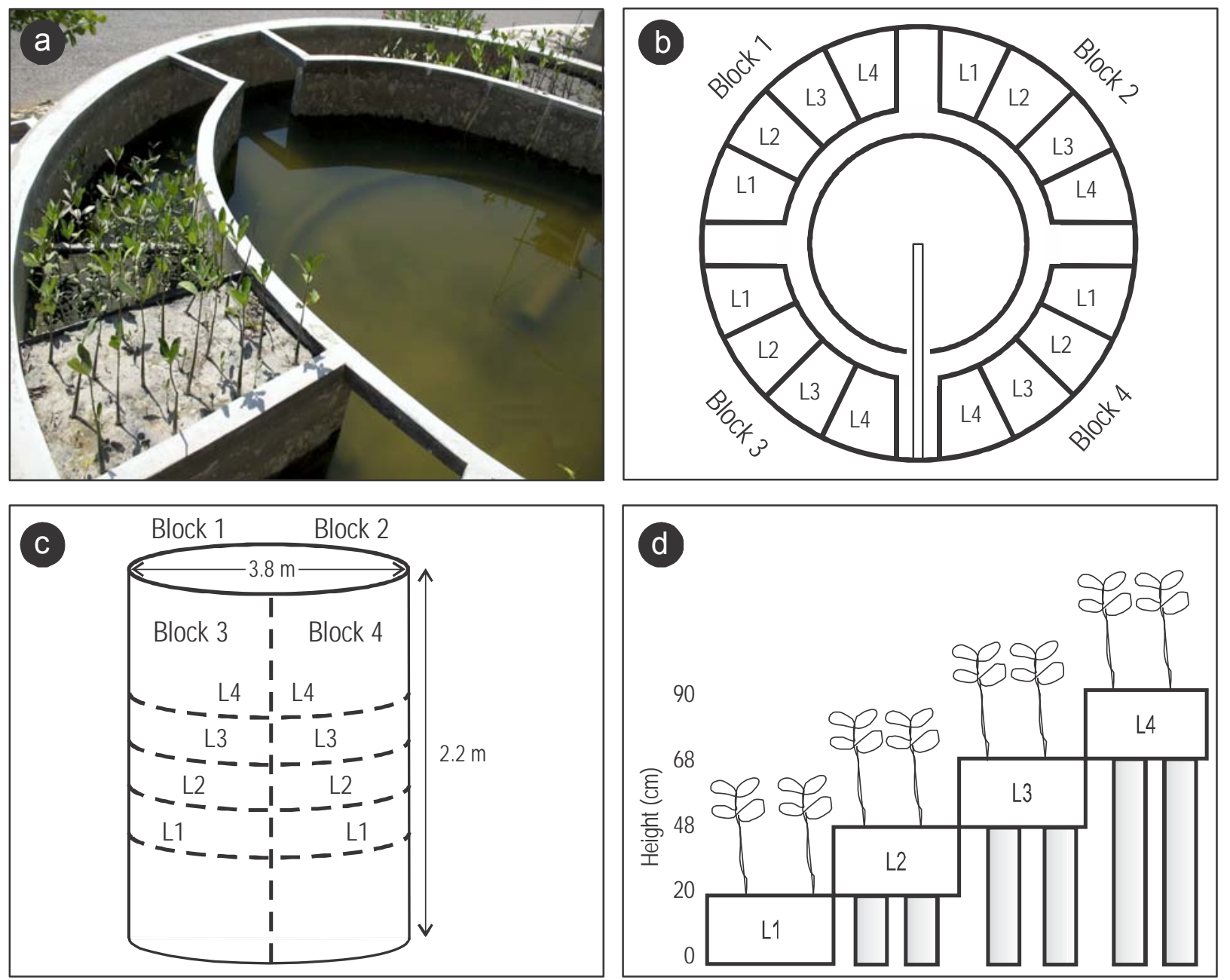

Figure 1. Design of the experimental tank: (a) photograph of the system, (b) cross section of the tank, (c) vertical structure of the tank, and (d) longitudinal section of one of the four blocks. L represents the inundation level. A total of 16 seedlings of Avicennia germinans, Laguncularia racemosa, and Rhizophora mangle were randomly planted in each block.

Figura 1. Diseño del tanque experimental: (a) fotografía del sistema, (b) corte transversal del tanque, (c) estructura vertical del tanque, (d) corte longitudinal de uno de los cuatro bloques. La letra L representa cada uno de los niveles. En cada bloque se sembraron un total de 16 plántulas de Avicennia germinans, Laguncularia racemosa y Rhizophora mangle de forma mixta.

channel (fig. 2b). Small groups of R. mangle shrubs are found in the intertidal zone, where small inlets create a lesspronounced topographic profile. In the supralittoral zone, only A. germinans shrubs are found without the presence of a salt marsh.

In a micro-basin, small inlets are responsible for the variability in the topographic profile (fig. 2c). The sublittoral zone is dominated by $R$. mangle under constant submersion; however, a transition between $R$. mangle and A. germinans shrubs occurs due to abrupt changes in slope. Figure $2 \mathrm{~d}$ represents an area where the tidal channel is occupied by L. racemosa. At this particular site, species composition in the supralittoral zone differs from the other three sites because only $R$. mangle and $L$. racemosa shrubs were found on elevated grounds. cada uno de los cuatro bloques se sembraron de forma mixta un total de 16 plántulas de las tres especies de mangle para evaluar las respuestas interespecíficas.

\section{RESUltados}

\section{Zonación subtropical de bosque de mangle}

La amplitud de marea en la laguna costera de Urías varía de $130 \mathrm{~cm}$ (marea viva) a $50 \mathrm{~cm}$ (marea muerta). La laguna costera muestra una variedad de patrones de zonación que depende del perfil topográfico, la pendiente y la distancia al canal de mareas. En este sistema, la zonación típica de un bosque de magle es encontrada donde la pendiente presenta una suave inclinación y una intensa acción de mareas 


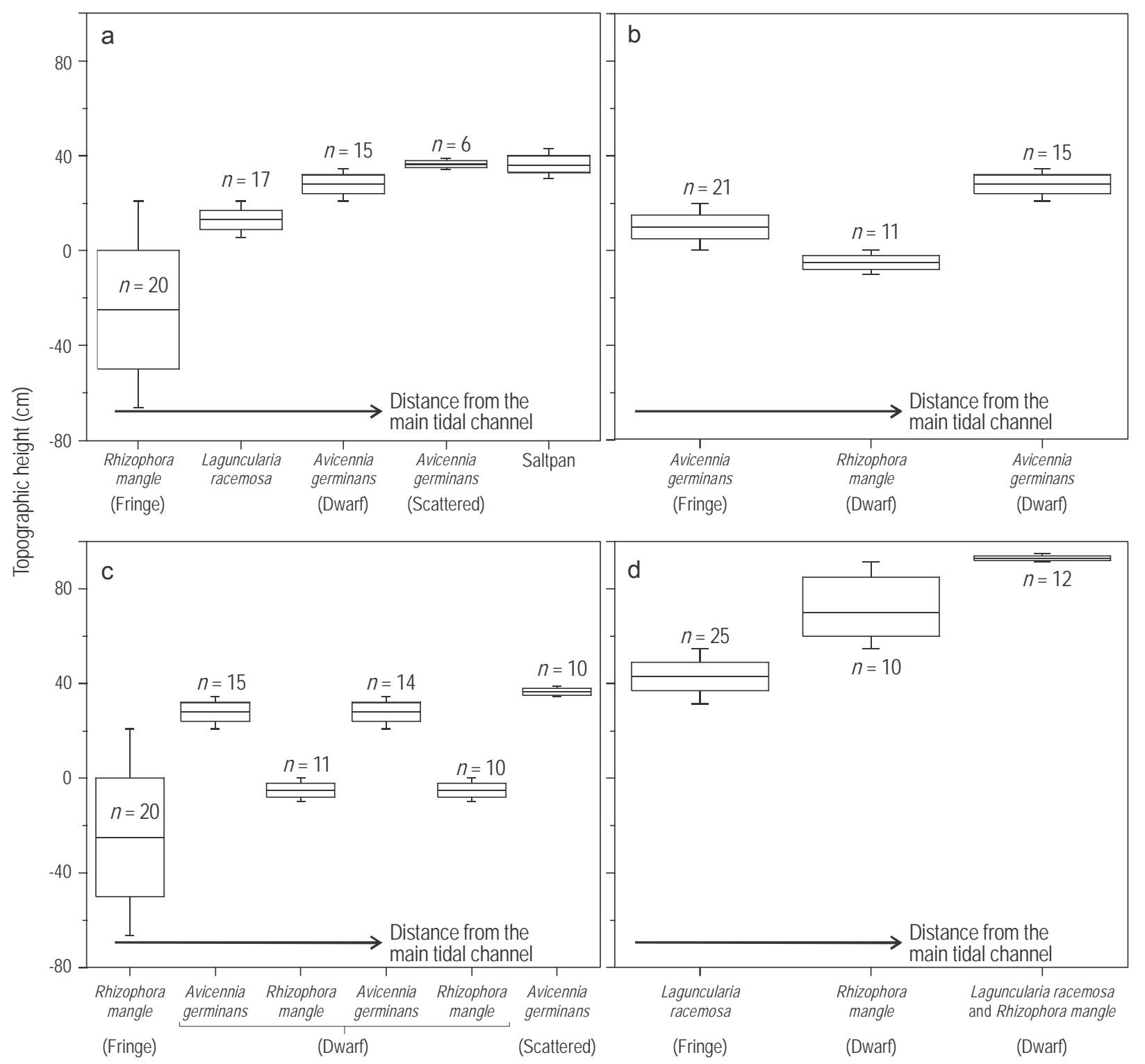

Figure 2. Box plot of the mangrove tree heights (relative to sea level) along four 20-m-long transects in the Urías coastal lagoon system on the Pacific coast of Mexico: (a) typical subtropical mangrove zonation, (b) fringe Avicennia germinans forest, (c) micro-basin mangrove forest, and (d) fringe Laguncularia racemosa forest. Each box presents $95 \%$ of the data, and the whiskers represent $5 \%$ of the data and the maximum and minimum values.

Figura 2. Diagrama de caja de las alturas (con relación al nivel del mar) de los árboles observados a lo largo de cuatro transectos de $20 \mathrm{~m}$ de longitud en el sistema lagunar de Urías en la costa mexicana del Pacífico: (a) bosque con una zonación típica de mangle subtropical, (b) bosque de Avicennia germinans tipo borde, (c) bosque con un perfil de microcuenca y (d) bosque de Laguncularia racemosa tipo borde. Cada caja presenta el 95\% de los datos, y las barras representan el 5\% restante incluyendo los valores máximos y mínimos.

\section{Mangrove growth and survival under different flood conditions}

Seedling height during the first 200 days was not considered in the linear regression analysis because there was no apparent difference among species (fig. 3). All the linear growth equations (table 1) showed high determination coefficients and a significant linear association between seedling height and time of growth for the four inundation levels. (fig. 2a). En esta zona, la vegetación en la zona sublitoral esta dominada por $R$. mangle, el cual esta inundado la mayor parte del tiempo. La zona media intermareal esta dominada por $L$. racemosa y matorrales densos de A. germinans. La composición de especies en la zona supralitoral consiste de matorrales dispersos de A. germinans cerca de la marisma. En la zona donde la clasificación fisiognómica de A. germinans es de tipo borde, existe un cambio abrupto en el perfil topográfico a lo largo del canal principal de mareas (fig. 2b). En 
There was a considerable difference in $R$. mangle seedling growth at inundation level 1 compared to levels 2, 3, and 4. At level 1, the growth of the A. germinans seedlings was similar to but slightly higher $(P<0.05)$ than that of the $L$. racemosa seedlings; however, all the $L$. racemosa seedlings died after 400 days of prolonged inundation (fig. 3a). At levels 2 and 3, L. racemosa presented the highest growth rate relative to A. germinans and $R$. mangle (fig. 3b, c). At level 2 , there were no apparent differences in A. germinans and $R$. mangle seedling growth until the end of the experiment, when the growth rate of $A$. germinans increased relative to that of $R$. mangle $(P<0.05)$ (fig. $3 b)$. At level $3, R$. mangle presented the lowest growth rate compared to the other two species. At level 4, all three species presented the lowest growth rates relative to the longer immersion periods.

\section{DiscussiON}

The interspecific variation in the physiological responses of A. germinans, L. racemosa, and $R$. mangle to factors associated with global warming, such as sea level rise, will result in modifications to the species composition and structure of mangrove communities (Ellison and Farnsworth 1997). Mangroves have developed morphological and physiological adaptations to cope with the effects of flooding (Saenger 2002), but growth patterns can change across salinity and hydroperiod gradients (Delgado et al. 2001, Cardona-Olarte et al. 2006). Hence, the spatial distribution of the three subtropical mangrove species in the intertidal zone can be affected by several factors that vary from the tidal channel to the inner mangrove areas, and can alter the biological functions controlling growth in these forests (Saenger 2002).

The intertidal distribution of mangrove propagules and seedlings is species specific and is mainly affected by tolerance to flooding, salinity, and shade, and nitrogen and phosphorus assimilation (Bashan et al. 1998, Vazquez et al. 2000, Allen et al. 2003, Vovides et al. 2010); however, seedling tolerance to flooding may be the most important, especially at subtropical latitudes where the environmental conditions contribute to a potential increase in stress (Floresde-Santiago et al. 2012). Previous studies (e.g., Bunt et al. 1985, Allen et al. 2003, He et al. 2007) have mentioned that seedling response to tidal flooding is an important factor determining the topographic height of a mangrove community. In subtropical regions, $R$. mangle trees tend to occupy permanently-flooded locations where the salinity is similar to that of seawater (35), and L. racemosa is commonly found at interior sites and in higher areas together with A. germinans (Delgado et al. 2001, Dahdouh-Guebas et al. 2004). In the present study, however, A. germinans, L. racemosa, and $R$. mangle forests were classified as fringe mangroves, which suggests that the degree of flooding tolerance depends on the geomorphology of the coastline. We therefore suggest that there are two main and very different physiognomic la zona intermareal, pequeñas agrupaciones de matorrales de mangle rojo son encontrados donde pequeños esteros crean un perfil topográfico de menor altura. En la zona supralitoral solamente matorrales de A. germinans son encontrados sin la presencia de una marisma.

La variabilidad en el perfil topográfico de una microcuenca es creada por la influencia de pequeños esteros (fig. 2c). La zona sublitoral está dominada por R. mangle, el cual siempre está inhundado; sin embargo, se presenta una transición entre matorrales de $R$. mangle y A. germinans debido a cambios abruptos en la pendiente. La figura $2 \mathrm{~d}$ representa una zona en donde el canal principal de mareas presenta un bosque de L. racemosa. En esta área particular, la composición de especies en la zona supralitoral difiere de las otras tres zonas debido a que únicamente $R$. mangle y L. racemosa fueron encontrados en forma de matorral a una altura elevada.

\section{Crecimiento y supervivencia de tres especies de mangle bajo diferentes intervalos de inundación}

Para el ánalisis de regresión lineal, no se tomó en cuenta la altura de las plántulas en los primeros 200 días porque no se observó un cambio aparente entre las especies (fig. 3). Todas las ecuaciones lineales de crecimiento (tabla 1) presentaron coeficientes de determinación muy altos y una relación lineal significativa entre la altura de las plántulas y el tiempo de crecimiento en los cuatro niveles de inundación analizados.

Hubo una gran diferencia en el crecimiento de $R$. mangle en el nivel 1 comparado con los niveles 2, 3 y 4 . Además, en el nivel 1, las plántulas de $L$. racemosa y A. germinans presentaron un crecimiento similar, aunque el crecimiento de A. germinans fue ligeramente mayor $(P<0.05)$; sin embargo, todas las plántulas de $L$. racemosa en el nivel 1 murieron después de 400 días de inundación prolongada (fig. 3a). Laguncularia racemosa presentó el mayor crecimiento en los niveles 2 y 3 en comparación con $A$. germinans y $R$. mangle (fig. $3 b, c)$. En el nivel 2, no hubo una aparente diferencia entre el crecimiento de $A$. germinans y $R$. mangle hasta el ultimo día del experimento, cuando A. germinans mostró un incremento en el crecimiento comparado con $R$. mangle $(P<0.05)$ (fig. 3b). En el nivel 3, R. mangle presentó el menor crecimiento comparado con las otras dos especies. En el nivel 4, las tres especies presentaron el menor crecimiento en comparación con los niveles de mayor inundación.

\section{DISCUSIÓN}

Las variaciones interespecíficas en las respuestas fisiológicas de $A$. germinans, $L$. racemosa y $R$. mangle ante factores asociados con el calentamiento global, como la variabilidad en el incremento del nivel del mar, van a ocasionar modificaciones en la composición de especies y estructura de comunidades de un bosque de mangle (Ellison y 


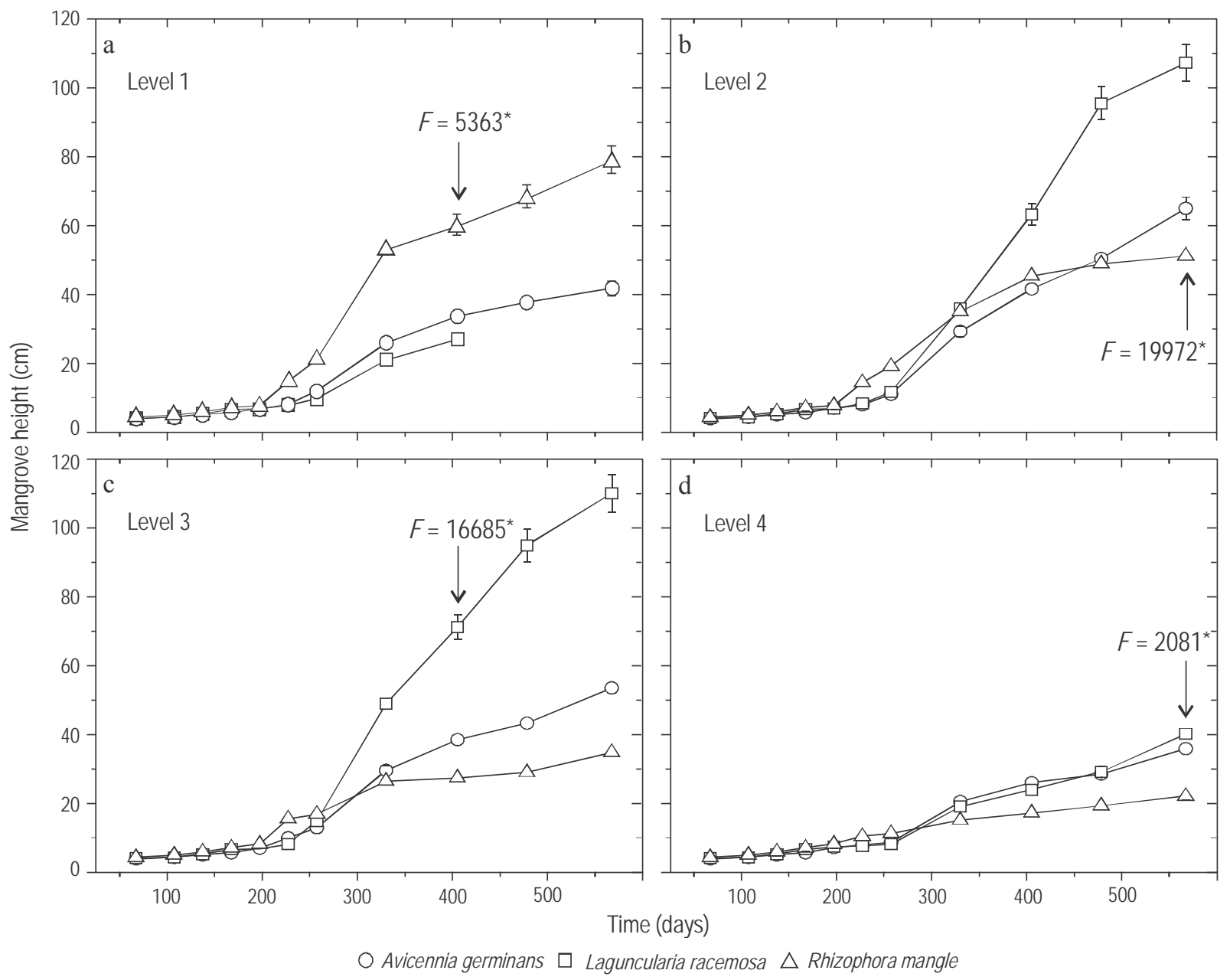

Figure 3. Height of Avicennia germinans, Laguncularia racemosa, and Rhizophora mangle seedlings exposed to different inundation conditions over 570 days: level 1 was flooded for $10 \mathrm{~h}$ (a), level 2 for 6 horas (b), level 3 for $2 \mathrm{~h}$ (c), and level 4 for 6 min (d). The asterisk indicates significance at $\alpha=0.05$. Error bars not shown are smaller than symbol size.

Figura 3. Altura de plántulas de Avicennia germinans, Laguncularia racemosa y Rhizophora mangle expuestas a cuatro niveles de inundación a lo largo de 570 días. Nivel 1 fue inundado por 10 horas (a); nivel 2 por 6 horas (b); nivel 3 por 2 horas (c); y nivel 4 por 6 minutos (d). El asterísco indica significancia a $\alpha=0.05$. No se muestran las barras de error que son más pequeñas que el tamaño del símbolo.

mangrove types in subtropical areas: few fringe mangrove forests and extensive basin mangrove forests (i.e., shrubs).

In the absence of erosion, accretion, and other stressors like pollutants, the degree of flooding tolerance differs among mangrove species and plays an important role in determining the topographic height of a mangrove community (Saenger 2002). Our results show that the tide and topographic profile strongly influence the growth of A. germinans, L. racemosa, and $R$. mangle. Of these three species, $R$. mangle tolerates longer periods of inundation. Ellison and Farnsworth (1993) reported that $R$. mangle seedlings grew more rapidly in terms of height, diameter, leaf production, and biomass in areas subject to prolonged flooding than in areas where flooding was less frequent, and all the seedlings died in higher areas where flooding was minimum. More recently, Cardona-Olarte et al. (2006) reported that,
Farnsworth 1997). Los mangles producen adaptaciones morfológicas y fisiológicas para contrarrestar los efectos de inundación (Saenger 2002); sin embargo, pueden haber diferentes patrones en el crecimiento de acuerdo con los gradientes de la salinidad y el hidroperiodo (Delgado et al. 2001, Cardona-Olarte et al. 2006). Como consecuencia, la distribución espacial de las tres especies de mangle subtropical en la zona intermareal puede ser afectada por varios factores que varían desde el canal de mareas hasta el interior de la distribución, y que pueden ocasionar cambios en las funciones biológicas que controlan el potencial de crecimiento en estos bosques (Saenger 2002).

La distribución intermareal de propágulos y plántulas de mangle depende de la especie y es afectada principalmente por la tolerancia a las inundaciones, la salinidad y la sombra, y la asimilación de nitrógeno y fósforo (Bashan et al. 1998, 
Table 1. Analysis of variance of the linear regressions between mangrove height and time as of day 200 at four inundation levels (L) for three mangrove species. The coefficient of determination $\left(R^{2}\right)$ and observed $F$ value are also given. The asterisk represents significant $F$ values at $\alpha$ $=0.05$ (critical $F=4.96, n-p=10$ ) and $\alpha=0.01$ (critical $F=10.04, n-p=10$ ), where $n$ represents the total number of data and $p$ the total number of variables.

Tabla 1. Análisis de varianza de las regresiones lineales entre la altura del mangle y el tiempo a partir del día 200 a los cuatro niveles (L) de inundación para cada una de las tres especies de mangle. Se muestran el coeficiente de determinación $\left(R^{2}\right)$ y el valor observado de $F$. El asterisco representa valores significativos de $F$ a $\alpha=0.05$ ( $F$ crítico $=4.96, n-p=10)$ y $\alpha=0.01(F$ crítico $=10.04, n-p=10)$, donde $n$ representa el número total de datos y $p$ el número total de variables.

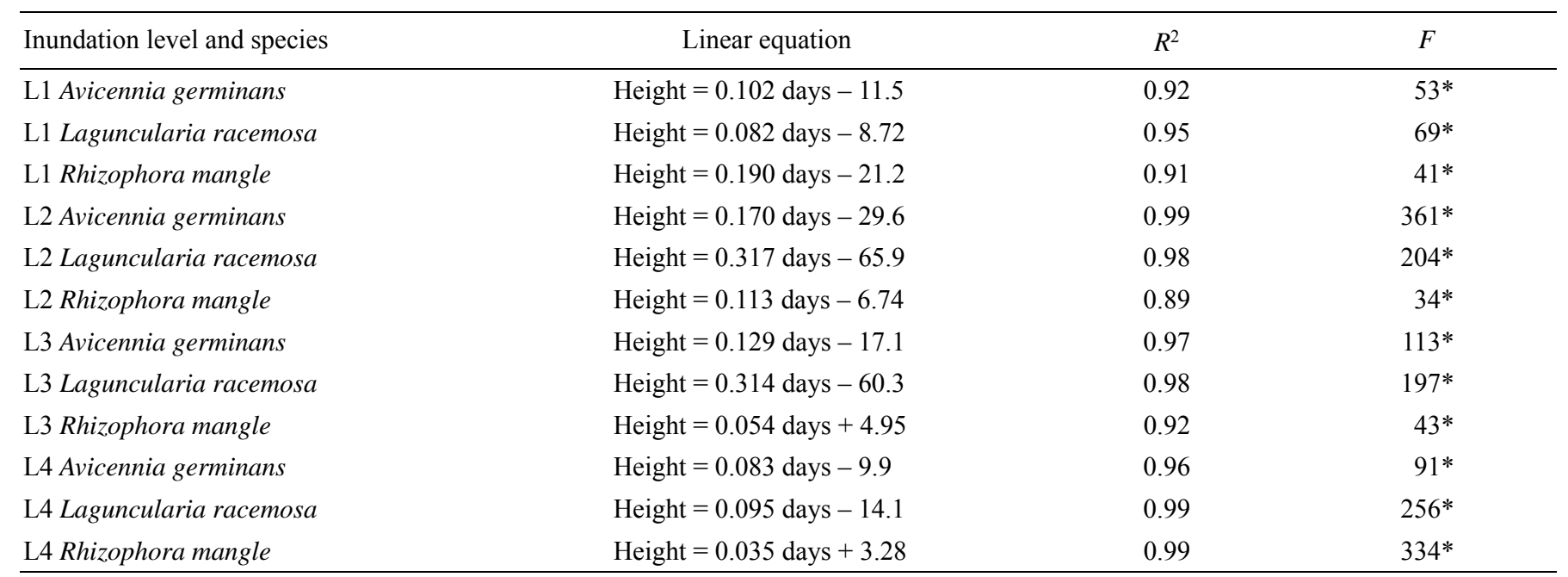

under experimental conditions, $R$. mangle seedlings showed reduced growth when they were not in an optimum distribution zone. They also concluded that the growth performance of $L$. racemosa depends on the hydroperiod and salinity ranges, with a better response in the hydroperiod.

In the present study, the growth response of L. racemosa to inundation gradients differs among the four height levels. The $L$. racemosa seedlings did not survive when they were exposed to prolonged inundation (level 1). The fact that this species is found along the main tidal channel indicates that the topographic profile in subtropical coastal lagoons plays an important role in the survival of this species in a heavily flooded area. Cardona-Olarte et al. (2006) reported that $R$. mangle and $L$. racemosa responded differently to the combined effects of hydroperiod and salinity in mixed cultures, with $L$. racemosa presenting better growth. This latter species typically shows better growth relative to $R$. mangle under low stress conditions (Krauss et al. 2006). In our experimental tank, where low stress conditions were maintained, the relative increase in the growth rate of $L$. racemosa gives this species the advantage of colonizing new areas rapidly. When $L$. racemosa and $R$. mangle share the same habitat, $L$. racemosa tends to grow faster, giving it a competitive advantage over $R$. mangle. Interestingly, in our study, $L$. racemosa presented better growth rates at levels 2 and 3 , when the inundation frequency was lower than at level 1 , which is when $R$. mangle presented the highest growth. A consequence of the sensitivity shown by $L$. racemosa to prolonged flooding is that this species tends to restrict its spatial distribution to areas where inundations are less frequent and
Vazquez et al. 2000, Allen et al. 2003, Vovides et al. 2010); sin embargo, la tolerancia de las plántulas a los periodos de inundación puede ser más importante, especialmente en latitudes subtropicales donde las condiciones ambientales contribuyen a un potencial incremento en el estrés (Flores-deSantiago et al. 2012). Algunos estudios (e.g., Bunt et al. 1985, Allen et al. 2003, He et al. 2007) han demostrado que la respuesta de las plántulas a los periodos de inundación es un factor importante en determinar la altura topográfica de una comunidad de mangle. En regiones subtropicales, los árboles de $R$. mangle tienden a ocupar localidades donde ocurre una inundación permanente y la salinidad es similar a la del agua de mar (35), y L. racemosa es común en localidades interiores y en zonas elevadas junto con arbustos de A. germinans (Delgado et al. 2001, Dahdouh-Guebas et al. 2004). Sin embargo, en nuestra investigación, A. germinans, $L$. racemosa y $R$. mangle presentaron una clasificación fisiognómica tipo borde, lo cual sugiere que el grado de tolerancia a la inundación depende de la geomorfología en la línea de costa. Consecuentemente, nosotros sugerimos que hay dos principales y muy diferentes grupos ecológicos de mangle en zonas subtropicales: una pequeña franja de comunidad tipo borde y a una extensa zona de mangle tipo cuenca (i.e., matorral).

En ausencia de erosión, acreción y otras alteraciones como los contaminantes, el grado de tolerancia a las inundaciones es muy diferente entre las especies de mangle y juega un papel muy importante en la determinación de la altura topográfica de una comunidad de mangle (Saenger 2002). Nuestros resultados muestran que las tres especies de mangle 
its performance is superior to that of $R$. mangle (CardonaOlarte et al. 2006).

Like L. racemosa, A. germinans presented greater growth at levels 2 and 3, but the growth rate of this species was lower than that of $L$. racemosa. An explanation for this is that Avicennia is less adaptable to flooding than Laguncularia (He et al. 2007). Delgado et al. (2001), on the other hand, found that the growth rate of Avicennia and Laguncularia seedlings exposed to simulated tidal inundation was high and that there were no differences between both species. Surprisingly, we observed that in the supralittoral zone (i.e., level 4), $L$. racemosa and $A$. germinans did not show apparent differences in growth, indicating that both species can grow when optimum salinity (i.e., 15) is maintained. In subtropical areas, however, the increase in salinity near the salt marsh is largely responsible for the zonation patterns of L. racemosa and A. germinans.

Monitoring the optimum inundation periods for the growth and survival of mangrove species in subtropical environments is important to predict their responses to sea level rise. Our results show that the three subtropical mangrove species typical of the American continent vary in their tolerance to flooding and topographic level; however, their tolerance to the combined effects of salinity and flooding needs to be better studied in subtropical, arid environments. It is reasonable to conclude that the differences in mangrove growth and survival are related to distinct physiological factors, each species responding according to the local environments and ecological controls.

\section{ACKNOWLEDGMENTS}

The first author acknowledges support from the National Council for Science and Technology (CONACYT, Mexico; project No. 202273). Funding for the field work was provided by the Universidad Nacional Autónoma de México (UNAM, Instituto de Ciencias del Mar y Limnología) to the second author. The third author acknowledges receipt of a grant from UNAM (Dirección General Asuntos del Personal Académico).

English translation by Christine Harris.

\section{REFERENCES}

AboEl-Nil MM. 2001. Growth and establishment of mangrove (Avicennia marina) on the coastlines of Kuwait. Wetlands Ecol. Manage. 9: 421-428. http://dx.doi.org/10.1023/A:1012098525918

Allen JA, Krauss KW, Hauff RD. 2003. Factors limiting the intertidal distribution of the mangrove species Xylocarpus granatum. Oecologia 135: 110-121. http://dx.doi.org/10.1007/s00442-002-1167-2

Bashan Y, Holguin G. 2002. Plant growth-promoting bacteria: A potential tool for arid mangrove reforestation. Trees 16: $159-166$.

http://dx.doi.org/10.1007/s00468-001-0152-4 dependen en gran medida de la influencia de mareas y la altura del perfil topográfico para desarrollarse óptimamente. En el caso de $R$. mangle, esta especie tolera los mayores periodos de inundación comparada con A.geminans y L. racemosa. Ellison y Farnsworth (1993) registraron que las plántulas de $R$. mangle crecieron mas rápido en términos de altura, diámetro, producción de hojas y biomasa en las zonas con periodos largos de inundación que en las zonas donde los periodos de inundación fueron cortos, y todas las plántulas murieron en las zonas más altas donde la inundación fue mínima. En un estudio experimental más reciente, CardonaOlarte et al. (2006) registraron que el crecimiento de las plántulas de $R$. mangle fue menor cuando esta especie no estaba en una zona óptima de distribución. Además, los mismos autores concluyeron que las respuestas en crecimiento de $L$. racemosa dependen de los intervalos de salinidad y el hidroperiodo, y la respuesta fue mejor en el hidroperiodo.

En nuestro experimento, las respuestas en el crecimiento de $L$. racemosa a gradientes de inundación difieren entre los cuatro niveles de altura. Las plántulas de $L$. racemosa no sobrevivieron en el nivel 1 , donde los intervalos de inundación fueron mayores. El hecho de que esta especie es encontrada a lo largo del canal principal de inundación muestra que el perfil topográfico en las lagunas costeras subtropicales juega un papel muy importante en la supervivencia de esta especie en una zona de inundación prolongada. Se ha registrado que $L$. racemosa y $R$. mangle responden diferente a la combinación de los efectos del hidroperiodo y la salinidad en cultivos mixtos, donde $L$. racemosa presenta un mayor crecimiento (Cardona-Olarte et al. 2006). Este incremento en el crecimiento de $L$. racemosa relativo a $R$. mangle es característico de esta especie bajo condiciones mínimas de estrés (Krauss et al. 2006). Según lo observado en nuestro tanque experimental, donde las condiciones se mantuvieron con un mínimo de estrés, los incrementos relativos en el crecimiento de $L$. racemosa le pueden dar a esta especie una ventaja en colonizar rápidamente áreas nuevas. Cuando L. racemosa y $R$. mangle comparten el mismo hábitat, L. racemosa tiende a crecer más rápido, lo cual es una ventaja competitiva sobre $R$. mangle. Interesantemente, en nuestra investigación, $L$. racemosa presentó el mayor crecimiento en los niveles 2 y 3 , donde la frecuencia de inundación fue menor que en el nivel 1 , donde $R$. mangle se desarrolló en mejor medida. Una consecuencia de esta respuesta sensible de L racemosa a las inundaciones es que esta especie tiende a restringirse en su distribución espacial hacia áreas donde las inundaciones son menos frecuentes y su desarrollo es óptimo y mucho mayor que $R$. mangle (Cardona-Olarte et al. 2006).

Al igual que $L$. racemosa, A. germinans presentó el mayor crecimiento en los niveles 2 y 3 , pero el crecimiento de esta especie fue menor comparado con L. racemosa. Esto puede deberse a que Avicennia es menos adaptable a las inundaciones que Laguncularia (He et al. 2007). Por otro lado, Delgado et al. (2001) encontraron que el crecimiento de plántulas de Avicennia y Laguncularia bajo una inundación 
Bashan Y, Esther-Puente M, Myrold DD, Toledo G. 1998. In vitro transfer of fixed nitrogen from diazotrophic filamentous cyanobacteria to black mangrove seedlings. FEMS Microbiol. Ecol. 26: 165-170. http://dx.doi.org/10.1111/j.1574-6941.1998.tb00502.x

Bashan Y, Moreno M, Salazar G, Álvarez L. 2013. Restoration and recovery of hurricane-damaged mangroves using the knickpoint retreat effect and tides as dredging tools. J. Environ. Manage. 116: 196-203.

http://dx.doi.org/10.1016/j.jenvman.2012.11.045

Blasco F, Saenger P, Janodet E. 1996. Mangroves as indicators of coastal change. Catena 27: 167-178. http://dx.doi.org/10.1016/0341-8162(96)00013-6

Bryce S, Larcombe P, Ridd PV. 2003. Hydrodynamic and geomorphological controls on suspended sediment transport in mangrove creek systems, a case study: Cocoa Creek, Townsville, Australia. Estuar. Coast. Shelf Sci. 56: 415-431. http://dx.doi.org/10.1016/S0272-7714(02)00192-0

Bunt JS. 1996. Mangrove zonation: An examination of data from seventeen riverine estuaries in tropical Australia. Ann. Bot. 78: 333-341. http://dx.doi.org/10.1006/anbo.1996.0128

Bunt JS, Williams WT, Bunt ED. 1985. Mangrove species distribution in relation to tide at the seafront and up rivers. Aust. J. Mar. Freshw. Res. 36: 481-492. http://dx.doi.org/10.1071/MF9850481

Cardona-Olarte P, Twilley RR, Krauss KW, Rivera-Monroy V. 2006. Responses of neotropical mangrove seedlings grown in monoculture and mixed culture under treatments of hydroperiod and salinity. Hydrobiologia 569: 325-341. http://dx.doi.org/10.1007/s10750-006-0140-1

Dahdouh-Guebas F, Bondt RD, Abeysinghe PD, Kairo JG, Cannicci S, Triest L, Koedam N. 2004. Comparative study of the disjunct zonation pattern of the grey mangrove Avicennia marina (Forsk.) Vierh. in Gazi Bay (Kenya). Bull. Mar. Sci. 74: 237-252.

De-León-Herrera R, Flores-Verdugo F, Flores-de-Santiago F, González-Farías F. Nutrient removal in a closed silvofishery system using three mangrove species (Avicennia germinans, Laguncularia racemosa, and Rhizophora mangle). Mar. Pollut. Bull. (in press).

Delgado P, Hensel PF, Jiménez JA, Day JW. 2001. The importance of propagule establishment and physical factors in mangrove distributional patterns in a Costa Rican estuary. Aquat. Bot. 71: $157-178$. http://dx.doi.org/10.1016/S0304-3770(01)00188-7

Dittmar T, Hertkorn N, Kattner G, Lara RJ. 2006. Mangroves, a major source of dissolved organic carbon to the oceans. Global Biogeochem. Cycles 20: GB1012. http://dx.doi.org/10.1029/2005GB002570

Duke NC, Meynecke JO, Dittman S, Ellison AM, Anger K, Berger U, Cannicci S, Diele K, Ewel KC, Field CD, Koedam N, Lee SY, Marchand C, Nordhaus I, Dahdouh-Guebas F. 2007. A world without mangroves? Science 317: 41-42. http://dx.doi.org/10.1126/science.317.5834.41b

Ellison AM, Farnsworth EJ. 1993. Seedling survivorship, growth, and response to disturbance in Belizean mangal. Am. J. Bot. 80: 1137-1145. http://dx.doi.org/10.2307/2445541

Ellison AM, Farnsworth EJ. 1997. Simulated sea level change alters anatomy, physiology, growth, and reproduction of red mangrove (Rhizophora mangle L.). Oecologia 112: 435-446. http://dx.doi.org/10.1007/s004420050330

Ellison AM, Mukherjee BB, Karim A. 2000. Testing patterns of zonation in mangroves: Scale dependence and environmental simulada de acuerdo con el régimen de mareas fue alto y no hubo diferencias entre las dos especies. Sorprendentemente, en nuestro experimento observamos que en la zona supralitoral (i.e., nivel 4), L. racemosa y A. germinans no presentaron cambios aparentes en el crecimiento, lo cual indica que ambas especies se pueden desarrollar en esta zona seca cuando se mantiene una salinidad óptima (i.e., 15). Sin embargo, en zonas subtropicales, los patrones de zonación de $L$. racemosa y $A$. germinans se deben en gran medida al incremento en la salinidad cerca de la marisma.

El monitoreo de los periodos óptimos de inundación y el desarrollo y supervivencia de las especies de mangle en ambientes subtropicales es importante para predecir su respuesta a un posible cambio en el nivel del mar. Nuestros resultados muestran que las tres especies subtropicales de mangle típicas del continente americano difieren ampliamente en su tolerancia a la inundación y el nivel topográfico. Sin embargo, la tolerancia a la combinación de los efectos de salinidad e inundación es un tema que se tiene que investigar en ambientes áridos subtropicales. Es razonable concluir que las diferencias en el crecimiento y la supervivencia de las especies de mangle son atribuidas a los distintos factores fisiológicos, ya que cada especie de mangle responde dependiendo de los ambientes locales y los controles ecológicos.

\section{Agradecimientos}

El primer autor agradece el apoyo financiero por parte del Consejo Nacional de Ciencia y Tecnología (CONACYT, proyecto No. 202273) de México. El financiamiento para el trabajo de campo fue proveído por el segundo autor a través de la Universidad Nacional Autónoma de México (UNAM, Instituto de Ciencias del Mar y Limnología). El tercer autor agradece el financiamiento otorgado por la UNAM a través de la Dirección General Asuntos del Personal Académico.

correlates in the Sundarbans of Bangladesh. J. Ecol. 88: 813-824.

http://dx.doi.org/10.1046/j.1365-2745.2000.00500.x

Field CD. 1995. Impact of expected climate change on mangroves. Hydrobiologia 106: 75-81.

http://dx.doi.org/10.1007/978-94-011-0289-6_10

Flores-de-Santiago F, Kovacs JM, Flores-Verdugo F. 2012. Seasonal changes in leaf chlorophyll $a$ content and morphology in a subtropical mangrove forest of the Mexican Pacific. Mar. Ecol. Prog. Ser. 444: 57-68.

http://dx.doi.org/10.3354/meps09474

Flores-de-Santiago F, Kovacs JM, Flores-Verdugo F. 2013a. The influence of seasonality in estimating mangrove leaf chlorophyll- $a$ content from hyperspectral data. Wetlands Ecol. Manage. 21: 193-207.

http://dx.doi.org/10.1007/s11273-013-9290x

Flores-de-Santiago F, Kovacs JM, Flores-Verdugo F. $2013 \mathrm{~b}$. Assessing the utility of a portable pocket instrument for estimating seasonal mangrove leaf chlorophyll contents. Bull. Mar. Sci. 89: 621-633.

http://dx.doi.org/10.5343/bms.2012.1032 
Flores-Verdugo F, Day JW, Briseño-Dueñas R. 1987. Structure, litter fall, decomposition, and detritus dynamics of mangroves in a Mexican coastal lagoon with an ephemeral inlet. Mar. Ecol. Prog. Ser. 35: 83-90.

http://dx.doi.org/10.3354/meps035083

García-Márquez F. 1985. El Topógrafo Descalzo: Manual de Topografía Aplicada. Editorial PAX México, México DF, 442 pp.

Gilman EL, Ellison J, Duke NC, Field C. 2008. Threats to mangrove from climate change and adaptation options: A review. Aquat. Bot. 89: 237-250. http://dx.doi.org/10.1016/j.aquabot.2007.12.009

Gilmor RG, Snedaker SC. 1993. Mangrove forests. In: Martin W et al. (eds.), Biodiversity of the Southeastern United States Lowland Terrestrial Communities. John Wiley, Toronto, pp. 165-198.

He B, Lai T, Fan H, Wang W, Zheng H. 2007. Comparison of flooding-tolerance in fur mangrove species in a diurnal tidal zone in the Beibu Gulf. Estuar. Coast. Shelf Sci. 74: 254-262. http://dx.doi.org/10.1016/j.ecss.2007.04.018

Holguin G, Vazquez P, Bashan Y. 2001. The role of sediment microorganisms in the productivity, conservation, and rehabilitation of the mangrove ecosystems: An overview. Biol. Fertility Soils 33: 265-278. http://dx.doi.org/10.1007/s003740000319

[INEGI] Instituto Nacional de Estadística y Geografía. 2012. Anuario Estadístico del Estado de Sinaloa. INEGI, Mexico City, $452 \mathrm{pp}$

Khan MA, Aziz I. 2001. Salinity tolerance in some mangrove species from Pakistan. Wetlands Ecol. Manage. 9: 229-233. http://dx.doi.org/10.1023/A:1011112908069

Komiyama A, Ong JE, Poungparn S. 2008. Allometry, biomass, and productivity of mangrove forest: A review. Aquat. Bot. 89: $128-137$.

http://dx.doi.org/10.1016/j.aquabot.2007.12.006

Kovacs JM, Liu Y, Zhang C, Flores-Verdugo F, Flores-de-Santiago F. 2011. A field based statistical approach for validating a remotely sensed mangrove forest classification scheme. Wetlands Ecol. Manage. 19: 409-421. http://dx.doi.org/10.1007/s11273-011-9225-3

Kovacs JM, Jiao X, Flores-de-Santiago F, Zhang C, Flores-Verdugo F. 2013a. Assessing relationships between Radarsat-2 C-band and structural parameters of a degraded mangrove forest. Int. J. Remote Sens. 34: 7002-7019. http://dx.doi.org/10.1080/01431161.2013.813090

Kovacs JM, Lu XX, Flores-Verdugo F, Zhang C, Flores-de-Santiago F, Jiao X. 2013b. Applications of ALOS PALSAR for monitoring biophysical parameters of a degraded black mangrove (Avicennia germinans) forest. ISPRS J. Photogramm. Remote Sens. 82: 102-111. http://dx.doi.org/10.1016/j.isprsjprs.2013.05.004

Krauss KW, Doyle TW, Twilley RR, Rivera-Monroy VH, Sullivan JK. 2006. Evaluating the relative contributions of hydroperiod and soil fertility on growth of south Florida mangroves. Hydrobiologia 569: 311-324. http://dx.doi.org/10.1007/s10750-006-0139-7

Kristensen E, Bouillonn S, Dittmar T, Marchand C. 2008. Organic carbon dynamics in mangrove ecosystems: A review. Aquat. Bot. 89: 201-219.

http://dx.doi.org/10.1016/j.aquabot.2007.12.005

McGuinness KA. 1997. Dispersal, establishment and survival of Ceriops tagal propagules in a north Australian mangrove forest. Oecologia 109: 80-87.

http://dx.doi.org/10.1007/s004420050061
McKee KL. 1995. Mangrove species distribution and propagules predation in Belize: An exception to the dominance-predation hypothesis. Biotropica 27: 334-345. http://dx.doi.org/10.2307/2388919

Polidoro BA, Carpenter KE, Collins L, Duke NC, Ellison AM, Ellison JC, Farnsworth EJ, Fernando ES, Kathiresan K, Koedam NE, Livingstone SR, Miyagi T, Moore GE, Nam VN, Ong JE, Primavera JH, Salmo III SG, Sanciangco JC, Sukardjo S, Wang Y, Yong JWH. 2010. The loss of species: Mangrove extinction risk and geographic areas of global concern. PLoS One 5: e10095. http://dx.doi.org/10.1371/journal.pone.0010095

Raven PH, Evert RF, Eichhorn SE. 1992. Biology of Plants. Worth Publishers, New York, 367 pp.

Saenger P. 2002. Mangrove Ecology, Silviculture and Conservation. Kluwer Academic Publisher, Dordrecht, 360 pp.

Spalding M, Kainuma M, Collins L. 2010. World Atlas of Mangroves. Earthscan Publisher, London, 304 pp.

Tomlinson PB. 1986. The Botany of Mangroves. Cambridge University Press, Cambridge, 405 pp.

Vazquez P, Holguin G. Puente ME, Lopez-Cortes A, Bashan Y. 2000. Phosphate-solubilizing microorganisms associated with the rhizosphere of mangroves in a semiarid coastal lagoon. Biol. Fertility Soils 30: 460-468. http://dx.doi.org/10.1007/s003740050024

Vovides AG, Bashan Y, López-Portillo JA, Guevara R. 2010. Nitrogen fixation in preserved, reforested, naturally regenerated and impaired mangroves as an indicator of functional restoration in mangroves in an arid region of Mexico. Restor. Ecol. 19: 236-244. http://dx.doi.org/10.1111/j.1526-100X.2010.00713.x

Wang W, Xiao Y, Chen L, Lin P. 2007. Leaf anatomical responses to periodical waterlogging in simulated semidiurnal tides in mangrove Bruguiera gymnorrhiza seedlings. Aquat. Bot. 86: $223-228$.

http://dx.doi.org/10.1016/j.aquabot.2006.10.003

Xiao Y, Jie Z, Wang M, Lin G, Wang W. 2009. Leaf and stem anatomical responses to periodical waterlogging in simulated tidal floods in mangrove Avicennia marina seedlings. Aquat. Bot. 91: 231-237. http://dx.doi.org/10.1016/j.aquabot.2009.07.001

Xiao Y, Wang W, Chen L. 2010. Stem anatomical variations in seedlings of the mangrove Bruguiera gymnorrhiza grown under periodical waterlogging. Flora 205: 499-505. http://dx.doi.org/10.1016/j.flora.2009.12.004

Ye Y, Tam NFY, Wong YS, Lu CY. 2003. Growth and physiological responses of two mangrove species (Bruguiera gymnorrhiza and Kandelia candel) to waterlogging. Environ. Exp. Bot. 49: 209-221. http://dx.doi.org/10.1016/S0098-8472(02)00071-0

Ye Y, Tam NFY, Wong YS, Lu CY. 2004. Does sea level rise influence propagule establishment, early growth and physiology of Kandelia candel and Bruguiera gymnorrhiza? J. Exp. Mar. Biol. Ecol. 306: 197-215. http://dx.doi.org/10.1016/j.jembe.2004.01.011

Ye Y, Gu YT, Gao HY, Lu CY. 2010. Combined effects of simulated tidal sea-level rise and salinity on seedlings of a mangrove species, Kandelia candel (L.) Druce. Hydrobiologia 641: 287-300.

http://dx.doi.org/10.1007/s10750-010-0099-9

Received August 2014, accepted November 2014. 